\title{
The International Politics of Natural Resources
}

Written under the Auspices of the Center for International Affairs, Harvard University 


\section{By the same author}

The Community of Oil Exporting Countries: A Study in Governmental Cooperation

A Financial Analysis of Middle Eastern Oil Concessions, 1901-65

An Analysis of World Energy Demand and

Supply, 1974-1985 (coauthor)

The Economic Development of Libya (coauthor)

Continuity and Change in the World Oil Industry (coeditor) 


\section{The International Politics}

of Natural Resources

\section{ZUHAYR MIKDASHI}


Copyright $\odot 1976$ by Cornell University

All rights reserved. Except for brief quotations in a review, this book, or parts thereof, must not be reproduced in any form without permission in writing from the publisher. For information address Cornell University Press, 124 Roberts Place, Ithaca, New York 14850.

First published 1976 by Cornell University Press.

Published in the United Kingdom by Cornell University Press Ltd., 2-4 Brook Street, London W1Y 1AA.

International Standard Book Number 0-8014-1001-0 Library of Congress Catalog Card Number 75-38002 Printed in the United States of America by Vail-Ballou Press, Inc. Librarians: Library of Congress cataloging information appears on the last page of the book. 
To UN Ideals 
